\title{
The Effect of Simulation-assisted Laboratory Applications on Pre-service Teachers' Attitudes towards Science Teaching
}

\author{
Şeyma Ulukök ${ }^{1}$, Uğur Sari ${ }^{2, *}$ \\ ${ }^{1}$ Department of Science Education, Faculty of Education, Bozok University, Turkey \\ ${ }^{2}$ Department of Science Education, Faculty of Education, Kırıkkale University, Turkey
}

Copyright $\bigcirc 2016$ by authors, all rights reserved. Authors agree that this article remains permanently open access under the terms of the Creative Commons Attribution License 4.0 International License

\begin{abstract}
In this study, the effects of computer-assisted laboratory applications on pre-service science teachers' attitudes towards science teaching were investigated and the opinions of the pre-service teachers about the application were also determined. The study sample consisted of 46 students studying science teaching Faculty of Education. The study data were obtained after students participated in an eight-week computer application embedded in the margins of the course "Laboratory Applications for Science Teaching II". Explanatory design, which is a mixed method research design, was used in the study. The quantitative data in the study are collected by using attitude scale and the qualitative data are collected via semi-structured interview form. For the analysis of the quantitative data, paired sample t-tests and bar graphics were used. For qualitative data analysis, content analysis was made. The results reveal that computer-assisted laboratory applications had a significant effect on pre-service teachers' attitudes towards science teaching. Moreover, the pre-service teachers defined the simulations as useful applications. They also indicated that the simulations were effective for their learning, supported their knowledge, and affected their attitude and motivation towards the lesson in a positive way. They also defined the characteristics they expected from simulation programs as being easy to use and enjoyable, and concretizing the information and developing creativity.
\end{abstract}

Keywords Attitude, Computer Simulations, Laboratory Applications, Science Teaching

\section{Introduction}

In today's circumstances where science and technology develops rapidly, science courses, which have a broad conceptual framework, are taught using several different methods, techniques and models. Of these, one of the most effective is the laboratory method, which provides permanent learning and also gives students the opportunity to work individually or in a group [1]. With effective use of a laboratory, theoretical knowledge is turned into practical knowledge, necessary experience is gained, manipulative skills are enhanced and the students learn to work together, share information and ideas, ask searching questions, determine the problems and find solutions by co-operating with the people around them [2]. For these reasons, we can claim that it is necessary for an effective science course to use laboratory applications [3].

Although it is stated in the literature that laboratories are important and laboratory applications are necessary for good science teaching, it is also noted that several factors restrict or negate the effective use of laboratory applications. These include: planning of the curriculum without considering the laboratory applications and short lesson times [4-6], negative views and attitudes of some teachers towards laboratory applications [7,8], lack of effective and sufficient teaching materials [9], not paying enough attention to safety in laboratory conditions [10], crowded classrooms [11], problems in classroom management and students' lack of background information about the topic [12] and using justification activities in laboratory instruction $[13,14]$. All these situations contribute to make it problematic the use and the effectiveness of the laboratory during the teaching. In order to overcome these kinds of problems and enhance the success of students in science, suitable alternative teaching methods have been developed. For example, the use of computer simulations that attract attention in education studies is one of the promising developments in computer technology with educational potential [15].

With the help of simulations that are easy to use in Science teaching, the students can observe natural events which cannot be seen directly because they may be too large or too small, too slow or too complex $[16,17]$. In addition to this, experiments that are difficult to control, are too expensive and hazardous and also too difficult or impossible to be 
realized in laboratory environments, can be performed via simulations in a virtual environment $[16,18,19]$. With computers, by producing a virtual environment in which several simulation applications appropriate to real environment can be realized; data that are difficult to obtain under laboratory conditions can be more easily achieved, experimental data can be processed rapidly and reliably, much data can be gathered in a short time and an experiment can be repeated as much as necessary $[16,18$, 20].

For successful application of computer simulations, which are an alternative model to the traditional laboratory model and have widespread use, the attitudes and motivations of science teachers and pre-service science teachers towards science are as important as the development of qualitative educational software. When the literature about science is reviewed, it is understood that science teachers play key roles in realizing the objectives of science education [21]. Teachers' successful realization of their responsibilities is directly related with the attitudes they develop towards their profession; the attitude towards science teaching is one of the important constituents of effective science teaching [22].

The attitudes of teachers towards science teaching affect not only their understanding of science and their thinking, but also implementations in science classes [23]. In their studies, Mattern and Schau [24] discovered that teachers with positive attitudes towards science and science teaching provided more productive classroom environments and, as a result, their students developed positive attitudes towards the course and teacher, which enhanced their success and motivation for studying science. Other studies in the field of science teaching showed a parallel relation between the attitudes of teachers towards science and science teaching and students' attitudes towards science. These attitudes towards science were shaped during pre-service times $[25,26]$.

Özdemir and Kaptan [22] stated that the learning-teaching process that pre-service science teachers experienced before their university education formed the basis for their attitude towards science teaching; the information students received in science courses until their undergraduate education, their success in these courses, the attitudes of their teachers, the experiments done in classes or in laboratories, and the classroom environment provide a basis for the attitudes developed by the students towards science teaching. During university education, teacher training programs, and their contents, the attitudes of instructors teaching science courses or any courses about science and science education have effects on pre-service teachers' attitudes towards science teaching. For carrying out intended in-class applications and to enable science teaching to reach the desired level, it is crucial to affect the attitudes of pre-service teachers towards science teaching in a positive way before they begin to work. Because of this, applications that will positively affect the attitude towards teaching should be used in faculties of education, where the attitudes of pre-service teachers are primarily shaped. Moreover, although the attitudes of teachers and pre-service teachers towards science are analyzed in detail, there are not enough studies on pre-service science teachers' attitudes towards science teaching. Therefore, the study aims to complete this gap in literature. In this study, we investigated the effect of simulation-assisted laboratory applications on the attitudes of pre-service teachers towards science teaching and teachers' opinions about the application. On the basis of the aim of the study, following research questions are determined:

- Do the simulation assisted laboratory applications have significant effect on attitudes of pre service teachers towards science teaching?

- What are the opinions of pre service teachers about simulation assisted laboratory applications and the programs used?

\section{Methodology of Research}

\subsection{General Background of Research}

In this study, explanatory design, which is one of the mixed method research designs, is used. In this kind of research that includes both qualitative and quantitative research designs, researchers first gather quantitative data, analyze them and then gather qualitative data in order to complete and refine them [27].

For the quantitative analysis part of the study, one sample pre-test/post-test design, which is among the experimental designs, is used. The characteristic feature of this design is that the study is done with one sample and the measurements of the sample are taken both before and after the method is applied [28]. For the qualitative part of the study, semi-structured interviews are carried out in order to reveal the opinions of pre-service teachers about the application.

\subsection{Sample of Research}

Participants of this study are 46 junior students studying Elementary Science Teaching at Kırıkkale University's Faculty of Education during the spring semester of 2011-2012 educational year. Convenience sampling is used for determining the participants [28]. The reason for choosing this method is that the preservice teachers have voluntarily accepted to participate in the study.

\subsection{Data Collection Tools}

\subsubsection{Science Teaching Attitude Scale}

The Science Attitude Scale, developed by Thompson and Shringley [30], and adapted by Tekkaya, Özkan and Çakıroğlu [29], is used in order to determine the attitudes of pre-service science teachers towards science teaching. The reliability coefficient of the 'Science Attitude Scale' is 0.83 and it is composed of 21 items in total, 11 of which are 
positive, 10 of which are negative. The item statements are ranked with a 5-point Likert style scale as: strongly agree, agree, undecided, disagree and strongly disagree. For the negative items in the scale, inverse scoring is performed.

\subsubsection{Interview form Regarding the Simulation Assisted Laboratory Applications}

To reveal the opinions of the pre-service teachers about simulation-assisted laboratory applications, a semi-structured interview form was developed. The questions on the form were developed by reviewing the literature. The views of two experts were taken to assess content validity and then the number of questions was reduced to four.

\subsection{Computer Simulations Used in the Study:}

For the experimental group, the Direct Current Kit, developed for Colorado University's Physics Education Technology (PhET) Project, Lab Faraday's Electromagnetic Simulation Software(http://phet.colarodo.edu/en/simulations), and "Crocodile Physics" Software (http://crocodile-clips.com /en/Crocodile-Physics) were used. The PhET software was adapted into Turkish and the relevant experiments were arranged in a way that the students could do the experiments easily by themselves in a virtual environment. The materials and tools necessary for the experiment were chosen from the tools menu and on a display screen they can be formed into any desired style; necessary controls and varieties were made by using the tools. Moreover, necessary measurement values were given by measurement tools; graphics can be drawn by graphic tools when needed, so that the data could be evaluated (Figure 1).

The Crocodile Physics program gives students an opportunity to perform virtual experiments, which are appropriate to their own designs, on the topics of electricity, motion, optics, and wave (Figure 2). In the Crocodile Physics program, the topics are presented as a whole. As seen in Figure 2, on the left of the screen, there are models separated by topic, object, and the menu that give opportunities for experiments. Users can form the tools and materials and options, such as graphics, they will use in the program by themselves and they can use these in a picture and in symbol form. On the upper part of the screen, there are shortcut keys that allow users to make changes on the mechanism of the experiment. Before carrying out the study, the researchers taught the pre-service teachers how to use the software for about two hours.

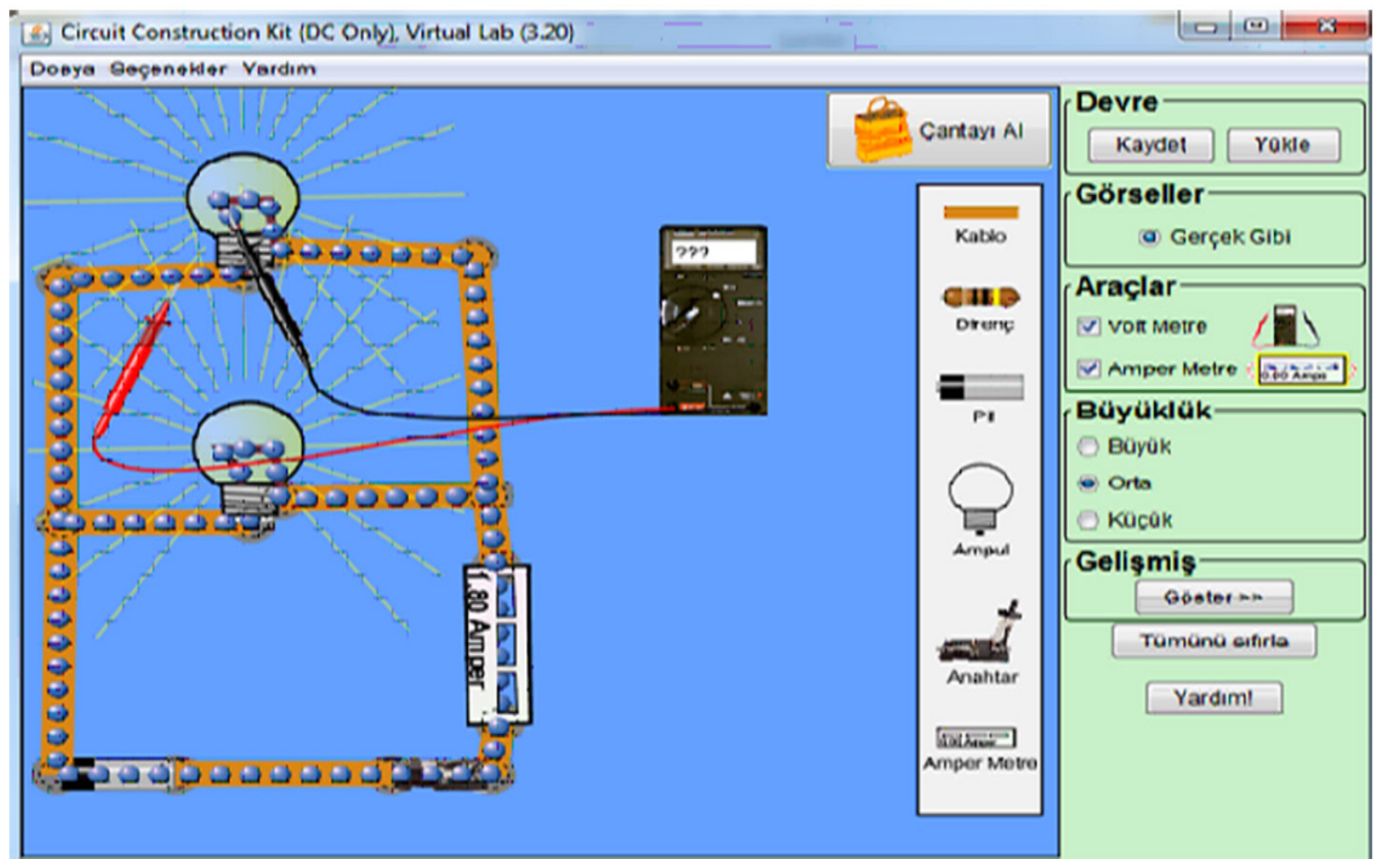

Figure 1. Phet simulation DC kit 


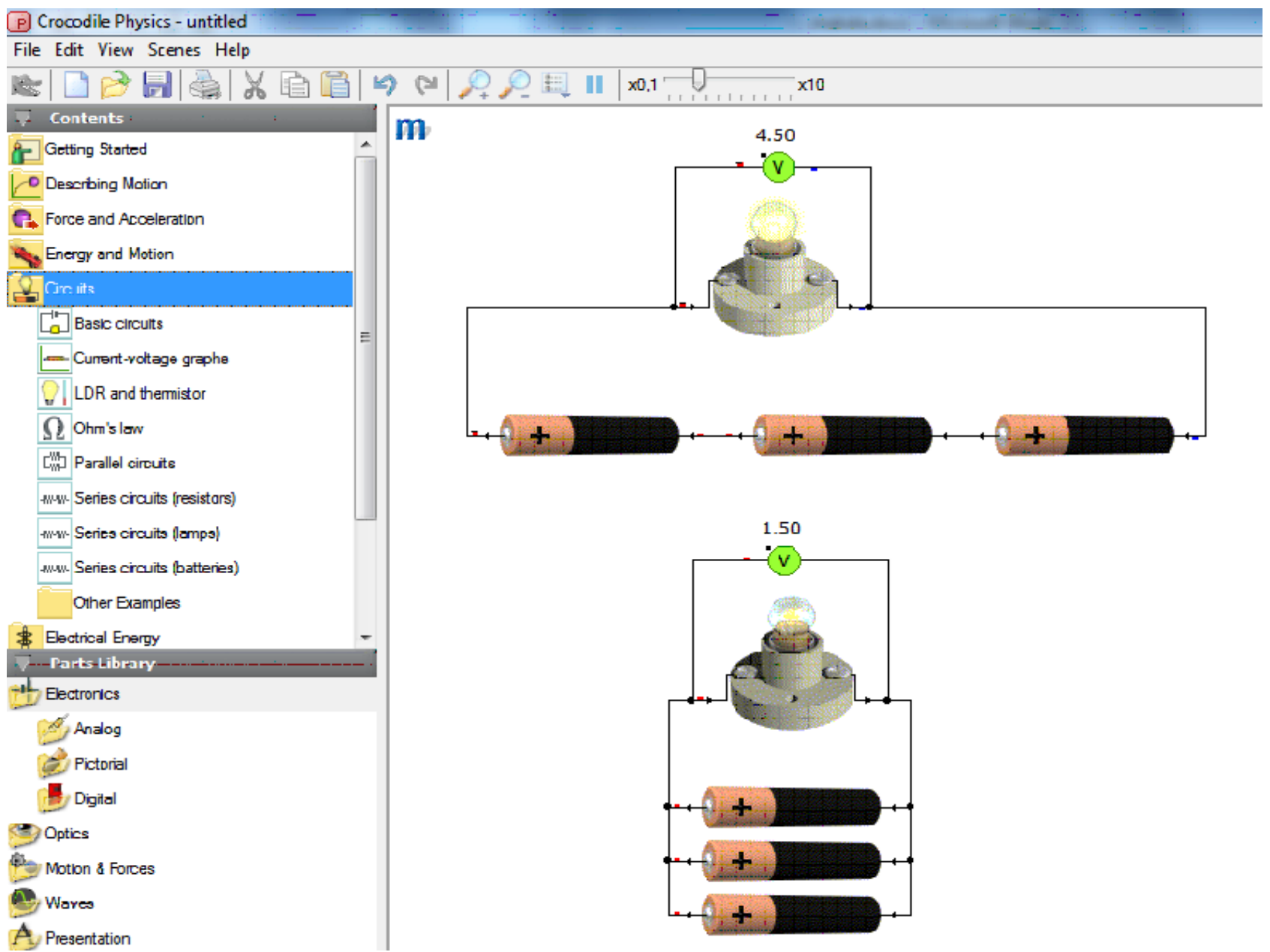

Figure 2. Crocodile physics program

\subsection{Implementation}

This study lasted for 8 weeks and 32 lessons within the margins of the "Laboratory Applications II for Science Teaching" course of the Elementary Science Teaching Program.

The instructions for laboratory experiments prepared by the researchers included the objectives for the topic 'Electricity in our lives'. 6th, $7^{\text {th }}$, and 8 th degrees science courses all have this topic, so the pre-service teachers will teach it in their future career. Under the supervision of the instructor responsible for the course, the application was conducted by the researcher in 4 lessons each week. Before the application, pre-service teachers were informed about the functions of the simulation activities and instructions of the experiments to be done; a model application was shown about a problem.

For an effective application, pre-service teachers were grouped and, while forming the groups, the researchers made sure to include teachers with different grade point averages (according to grade point averages of the course "Laboratory Applications II for Science Teaching") within each group to ensure heterogeneity within the groups but homogeneity among the groups. Later on, the pre-service teachers were divided into 9 groups, 5 groups of which had 6 people and 4 groups of 4 people. To decrease the number of pre-service teachers and to ease the researchers' work, the groups were divided into two. Five groups were randomly chosen for the first two lessons and the other five groups were asked to participate in the other two lessons. In order to eliminate the effect of time the groups were asked to take turns participating in the classes every week. After that, each group was provided with a computer. In the first lesson, when the application began, the first problem state of the study was delivered to pre-service teachers in a written format and group members were asked to detect the problem state by working together. During this phase, the researcher helped and guided the groups, where necessary, so that mistakes or deficiencies were detected. Until the next week's class, within a week, the pre-service teachers were asked to find the information sources and think about experiments for the solution of the problem by gathering together and sharing the information they got. So the students who found the necessary information first do the experiment that will be helpful for the solution of the problem in a virtual environment and then they do it in a real laboratory environment, integrating the information they got from the virtual experiment with the outcome of the real experiment and reach the solution of the problem. In the first 30 minutes 
of the next lesson, two or three groups were randomly chosen and asked to present the activities they did. If these presentations were not enough, other groups were asked to make presentations about the things they did. Under the guidance of the researcher, a discussion was held and the problem was solved so that the students could progress to the other problem. That week, students submitted the reports and presentation files they prepared. At the end of the application, post-tests were done and the voluntary pre-service teachers were asked to give their opinions about the application. The application phase lasted for 8 weeks total, including the preand post-tests.

\subsection{Data Analysis}

For quantitative data analysis, SPSS 17.00 was used. To identify significant differences between the pre-service teachers' attitude points, a paired sample t-test was used. Using descriptive statistics, the changes in the attitude points of the teachers were evaluated in detail with a bar chart.

For qualitative data analysis, the content analysis technique was used. Content analysis necessitates in-depth analysis of the collected data so, the themes that are not apparent are revealed. The data and certain concepts that are similar to each other are gathered together and arranged and interpreted in a way that the readers can understand [30].

Thus, with content analysis, a frame is formed from the collected data then codes, themes of these codes, and sub-themes are determined. The last form of the categorization process is evaluated by two field experts. The criticisms made by experts are compared with the categories of the researchers and the number of agreements and disagreements are determined. The reliability of the study was computed using the Miles and Huberman's [31] formula (Reliability $=$ Number of agreements $\backslash[$ Number of agreement + Number of disagreement]*100) and was $91 \%$. If the reliability coefficient is above $70 \%$, it is accepted as reliable for the research [31].

While reliability is one way to increase the credibility of the study results, basing the validity on a strong foundation is another way. Reporting the collected data in detail and an explanation of how the results were reached are important for the validity [30]. By considering this fact, analysis results are given in detail in order to ensure the validity. Later, the frequencies of these codes are shown on a chart in order to provide easiness for the reader and to visualize the study. The identities of the students interviewed were not revealed and numbers were assigned to each student (For female students: F1, F2...; for male students: M1, M2...).

\section{Results of Research}

\subsection{Results and Interpretations about Science Teaching Attitude Scale}

For the Science Teaching Attitude Scale, we found a significant difference between the pre- and post-test scores of pre-service teachers' (Table 1). These results show that simulation-assisted laboratory applications have a positive effect on the attitudes of pre-service teachers towards science teaching. We found that there was an $87 \%$ positive increase in the attitudes of pre-service teachers towards science teaching after performing the simulation-assisted laboratory activities (Fig. 3).

Table 1. Paired sample t-test results related to science teaching attitude scale scores

\begin{tabular}{ccccccc}
\hline & $\mathbf{N}$ & $\mathbf{M}$ & SD & df & $\mathbf{t}$ & $\mathbf{p}$ \\
\hline Pre test & 46 & 54.52 & 8.44 & & & \\
Post Test & 46 & 61.50 & 8.63 & & -10.87 & $* 0.00$ \\
\hline
\end{tabular}

${ }^{*} p<0.05$

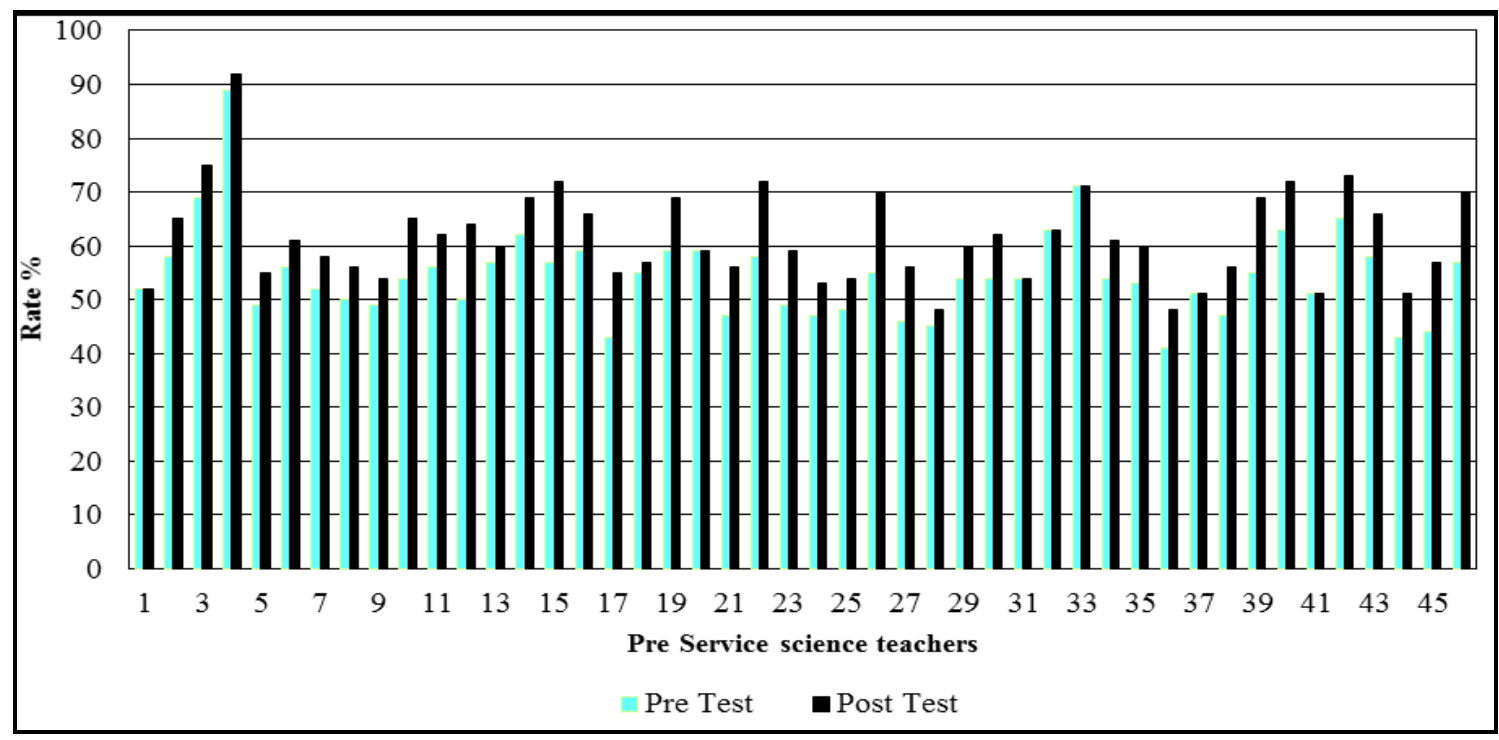

Figure 3. Pre-service teachers' science teaching attitude scale scores. 
Table 2. Student opinions about the question "Are the simulation applications useful for you? If yes please indicate in what ways they are useful?"

\begin{tabular}{|c|c|c|c|}
\hline Theme & Sub Theme & Codes & Frequencies(f) \\
\hline \multirow{12}{*}{ Uses } & \multirow{8}{*}{ Supporting effective learning and information } & Providing permanent learning & 17 \\
\hline & & Concretizing the information & 12 \\
\hline & & Making the learning easy & 6 \\
\hline & & Appealing to more than one sense & 6 \\
\hline & & Associating to real life & 5 \\
\hline & & Understanding the lesson better & 4 \\
\hline & & Recognizing the experiment tools better & 4 \\
\hline & & Completing the lack information & 3 \\
\hline & \multirow{4}{*}{ Attitudes and motivation towards the lesson } & Finding the lesson enjoyable & 18 \\
\hline & & Loving the lesson & 5 \\
\hline & & Motivation for studying the lesson & 5 \\
\hline & & Focusing attention on topic & 4 \\
\hline
\end{tabular}

\subsection{Qualitative Data Results}

Among 40 students who participated in the study, 36 volunteer students gave their opinions about the application. The opinions of the pre-service teachers about simulation-assisted laboratory applications were investigated using these answers. Common themes were determined and coded by referring directly to the opinions of students and these codes subsequently interpreted.

The students' answers to the question 'Are the simulation applications useful for you? If they are, please describe in what ways they are useful.' revealed that all of the students considered simulations to be useful. The points that students focus on most are that simulation applications are effective for learning; and that they concretize the abstract information and facilitate permanent learning (Table 2). Example opinions of pre-service teachers relevant to these points are: "I am very happy to get the education that our age necessitates because after this application, the things I have learned are more permanent." (F4); "As the application is more student-oriented and as it appeals to more than one sense, it enables the information I get to be more permanent" (M5); "Before the application I have thought that I would be unable to complete my knowledge of electricity but this application enables me to fill these gaps in my knowledge" (M2). Another point revealed here is that the simulations appeal to more senses and they enable students to better recognize the materials and tools of the experiment prior to the real laboratory application. For example: "As the application is more student-oriented and appeals to more than one sense, in other words, as more sense organs interact with each other, the information I get is more permanent" (M2); "This application is very useful for me because I have been confused about which tool works for which action and how they are used, but after this application, I can easily do experiments that I have had difficulty with before as I now better recognize the tools and materials" (F3).

In addition, students stated that the simulations provided an enjoyable learning environment, so that they enjoy the class; they love the class and their motivation for studying that class is enhanced (Table 2). The following pre-service teachers' statements are relevant to this finding: "At the beginning of the application I didn't expect that the class would be enjoyable. I expected that it would be a class with routine laboratory activities. But I was mistaken. The classes were very enjoyable" (F17); "I think this application is very enjoyable and instructive" (F11); "This application enables me to like laboratory classes that have been nightmares for me before and enhances my motivation for studying the class" (F28).

Among the answers to the question "What are the problems you have faced during the laboratory activities or what aspects of the application did you not like?" difficulty of use was the most important matter for the pre-service teachers (Table 3). With the statements "The application is very useful but as the program is in English and as I had never used this program before; I had difficulties during the simulation phase of the application" (F17); "My friends" leaving all burden of the application to me and not helping me for 8 weeks has caused me to have a negative attitude towards the class and the instructor" (F14); "As I couldn't identify adequate program resources and as I had to consult with the instructor whenever I had questions, I had difficulties during the application" (M15). "As the programs, especially the CrocodilePhyics program, are too confusing and leaves all of the work to the students, it has caused me difficulties to learn the program" (F23). The students indicated that they couldn't achieve all of the program's requirements and, as it is written in English, they found it difficult to use.

Being unfamiliar with this method also caused pre-service teachers to form a negative attitude towards the simulation applications. Statements such as: "the application is indisputably useful but it is a little difficult for me because this is the first time that I have carried out laboratory applications in this way and I am unacquainted with 
simulation applications" (F8); and "As we are accustomed to traditional laboratory methods, we have found this kind of lesson difficult. However, after we get accustomed to it, we have understood that it is a very important application and including it to our lessons is necessary" (F15), indicate that although they internalize the traditional laboratory method, they consider simulations important and necessary aspects of the taught courses. Moreover, the pre-service teachers complain about "their inefficiency in using the program"; "the program's requirement for creativity when designing the experiment"; "lack of collaboration within the groups"; and "their having negative attitudes towards computers". The students also indicate that they experienced barriers to using the program. For example: "As I was unacquainted with the program, I could not gain much experience from using it" (F6); "I hate using computers and I had to use a computer in this class. After all, I don't have sufficient ability for using computers" (F16). Those students that have weaknesses in using computers appeared to be prejudiced towards computer programs and therefore experience problems and difficulties with the simulation applications.

Fifty-nine percent of the pre-service teachers indicated a positive opinion for the question "Do you want to use these kinds of simulations in your class when you become teachers?". Most teachers that would like to implement the simulations felt that they were somehow advantageous: "they concretize the abstract topics"; "appeal to more than one sense"; and "they are enjoyable and interesting" (Table 4). Students' statements relevant to this include: "I absolutely want to use this kind of application when I become a teacher because it concretizes abstract topics such as electricity; it appeals to more than one sense and it makes the lesson more enjoyable and interesting" (M34); "As these kinds of applications are enjoyable and instructive, I want to use them in the future" (F26); "I am more willing to come to the classes now than I was previously. The lessons have been too monotonous for me before but now that I am able to have lessons with both my friends and my instructor they are very enjoyable for me" (M4).However, four of the pre-service teachers stated that they would not want to use this kind of applications when they become teachers, although they did indicate that they had internalized the constructive approach. The reasons given for this negative attitude included: that the application was too time-consuming; and that they are accustomed to traditional instruction and the close-ended experimental technique. For example: "This kind of application takes too much time, so I don't want to use them when I become a teacher" (F31); "It is obvious that the application has benefits but I prefer the traditional technique because I have become accustomed to it; I experienced only close-ended experiments and demonstration experiments throughout my own education" (M18); "This kind of an experiment is time-consuming and needs too much work. So I think it is more reasonable to use the traditional method" (F26). When the answers of the pre-service teachers to the question "Which of the programs you have used are most effective according to you and why?" were analysed, it was seen that while 19 teachers preferred the PhET programs, 10 of the teachers considered the Crocodile Physics program to be most effective; and 5 of the pre-service teachers did not express an opinion.

Table 3. Student opinions about the question "What are the problems you have faced during the simulation assisted laboratory activities or what aspects of the application did you not like?"

\begin{tabular}{cccc}
\hline Theme & Sub theme & Codes & Frequency(f) \\
\hline & & Difficulty in using the program & 9 \\
& & Not being familiar with the method & 3 \\
& Application's being tiring & 3 \\
Attitude & Legative attitude & Dislike of computer & 2 \\
& & Problems in collaboration & 2 \\
& The application's demands for too much work & (necessitating practicality) & Lack of source \\
\hline
\end{tabular}

Table 4. Pre-service teachers' opinions about the question "Do you want to use these kinds of simulations in your class when you become teachers?"

\begin{tabular}{cccc}
\hline \multirow{2}{*}{ Theme } & Sub Theme & Codes & Frequency (f) \\
\hline \multirow{3}{*}{ Application status } & I will use & Thinking that it is a useful application. & 20 \\
\cline { 2 - 4 } & \multirow{2}{*}{ I will not use } & Thinking that it is time consuming & 7 \\
& & Preferring another method over this method & 7 \\
\hline
\end{tabular}


Table 5. Pre-service teachers' opinions about programs.

\begin{tabular}{ccc}
\hline Category & PHet Frequency (f) & Crocodile Physics Frequency (f) \\
\hline Concretizing information & 10 & 5 \\
Being easy to use & 8 & 5 \\
Being more enjoyable & 7 & 5 \\
Being real-like & 6 & 3 \\
Making learning easy & 5 & 1 \\
Providing permanent learning & 4 & 2 \\
Strengthening conceptual learning & 4 & 1 \\
Saving time & 3 & 2 \\
Associated to real life & 3 & 6 \\
Enhancing creativity & 1 & \\
\hline
\end{tabular}

When the pre-service teachers' opinions about programs were analysed, the PhET programs were preferred because they: provided permanent learning; were easy to use; were enjoyable and life-like; made learning easy; developed conceptual learning; and are associated with real-life (Table 5). Examples of students' statements about the PhET program include: "For me the PhET program is more effective because it is more concrete. Its phase of experimental design is short, the tools are life-like and it is more colourful" (M16); "When I compare the programs, it is easier to use the PhET program; it is more enjoyable and visual" (F9). Whereas 6 of pre-service teachers indicated that they preferred Crocodile Physics because it is more effective for developing creativity. Some of their statements are as follows: "As the Crocodile Physics program leaves most of the phases to students, it improves creativity"; (F5), "Many of the phases in this program are open to exploration so it enables me to use my mind and to brain storm and in this way my creativity has developed" (M1).

\section{Conclusions and Discussion}

Here we show that simulation-assisted laboratory applications positively affect the attitudes of pre-service teachers towards science teaching. Analysis of pre-service teachers' opinions found that this was because of the simulation applications' ability to provide permanent learning by concretizing information, developing the students' conceptual understanding and making science enjoyable and accessible. Moreover, during the phase of preparation for the real laboratory environment, simulations affect the pre-service teachers' attitudes in a positive way because they enabled students to recognize the experimental tools and materials, build their preliminary knowledge and eliminate their motivation and anxiety problems, thus enabling them to encourage the students to design experiments.

However, the applications had no effect on 6 of the pre-service teachers' attitudes towards science teaching. These pre-service teachers were not accustomed to this technique and encountered difficulties using the program; these pre-service teachers did not enjoy using the computer and there were collaboration problems. We propose that the above mentioned difficulties resulted in them feeling anxiety towards the application.

Our findings are broadly in line with previous studies showing that simulation applications positively affect attitudes. White and Bodner [32] found that students enjoy using simulations and that this enables them to perform the application and learn easily. Moreover, they state that simulations are more effective in students' learning new concepts and methods. Rutten, Joolingen and Van der Veen [33] analysed a total of 510 articles published between 2001 and 2010 that had investigated the effect of simulations on science teaching. It was found that all of the analysed articles reported that the use of simulations has positive effects. Sarı, Ulukök and Özdemir [34] indicate that simulation applications have more positive effects on students' attitudes towards science lessons compared to traditional instructions. However, another study indicated that computer-assisted instructions have no effect on students' attitudes $[35,36]$. Çepni et al [35] suggest that applications performed over a short period of time do not effect students' attitudes.

Given that this studies' experiment group were using the simulation applications for the first time and that they were pre-service teachers, makes their opinions about the instruction important. When their opinions were analysed, it was found that the simulation applications have a positive effect on the learning environment and that all of the pre-service teachers considered the simulations to be useful. According to our study group, the simulation applications are advantageous because they: facilitate learning and support knowledge by providing opportunities to make learning easy; appeal to more than a single sense; concretize abstract information; provide permanent information; fill knowledge gaps; and link information to daily life.

Moreover, the pre-service teachers also found that the simulations: provided an enjoyable learning environment; increased recognition of experiment tools and materials; increased attention; and positively affected attitude and motivation, thus enabling students to enjoy the lesson. 
Fifty-nine percent of the pre-service teachers focused on the opportunities that the simulations provided and indicated that they would like to use these simulations in their lessons. This is in line with other studies demonstrating advantages of simulations [37-42] However, $40 \%$ of the pre-service teachers felt that the applications were time-consuming and that they would prefer a close-ended experimental technique with traditional instructions. This was mostly because these pre-service teachers were more familiar with these traditional approaches. These pre-service teachers indicated that they would not want to use this type of approach in their future lessons. These opinions were associated with students having difficulty using the simulations, leading to the perception that the applications are overly demanding. Some of the pre-service teachers' preference for traditional methods suggest that more time is required in order to foster positive attitudes towards simulation applications in teaching [35].

Among the simulation programs, the pre-service teachers mostly considered the PhET programs as most effective, although 6 pre-service teachers considered the Crocodile Physics program to be most effective because of its ability to increase creativity. The PhET simulations are presented to students as a single interface that is separated according to topic titles. In this interface, menu options (e.g., tools, materials and graphics) that belong to one topic are readily presented to the students. As a result, pre-service teachers focused on the PhET programs' ease of use in addition to their ability to concretize information, being life-like and enjoyable, making learning easy and strengthening conceptual understanding. Contrary to the PhET simulations, in the Crocodile Physics program, topics are given as a whole within a single program. The students are therefore required to generate the options that they will use in the program (e.g., tools, materials and graphics). Because of this feature, this program is more difficult to use. However, by choosing the tools and materials, as well as graphic menu options, the students are allowed to design the experiment, which they describe as an opportunity to improve their creativity. To conclude, our findings suggest that, in addition to being easy to use and providing an enjoyable environment, students also expect simulation programs to be open to free designs that will improve their creativity.

\section{Acknowledgements}

This study was produced from Master Thesis written by Şeyma ULUKÖK under the supervision of Asst. Prof. Dr. Uğur SARI.

\section{REFERENCES}

[1] Lawson, A.E.(1995). Science Teaching and the Development of Thinking. California: Wadsworth Press.
[2] Sar1, M. (2011). The importance of laboratory courses in science and technology teaching in primary education and the ideas of simple tools and instruments to evaluate teacher candidates on science experiments. 2nd International Conference on New Trends in Education and Their Implications. Antalya.

[3] Ayas, A, (2006). Using laboratory in science teaching. Retrieved from:http://w2.anadolu.edu.tr/aos/kitap/IOLTP/22 83/unite07.pdf

[4] Backus, L. (2005). A year without procedures. The Science Teacher, 72 (7), 54-58.

[5] Booth, G. (2001). Is inquiry the answer? Science Teacher, 68 (7), 57-59.

[6] Hackling, M.,Goodrum, D. \& Rennie, L. (2001). The state of science in Australian secondary schools. Australian Sciences Teachers' Journal, 47 (4), 12-17.

[7] Brown, P. L., Abell, S. K., Demir, A., \& Schmidt, F. J. (2006). College science teachers' views of classroom inquiry. Science Education, 90, 784-802.

[8] Costenson, K., \& Lawson, A. E. (1986). Why isn't inquiry used in more classrooms? American Biology Teacher, 48, 150-158.

[9] Lawson, A. E. (2000). Managing the inquiry classroom: problems \& solutions. The American Biology Teacher, 62 (9), 641-648.

[10] Deters, K. M. (2005). Student opinions regarding inquiry-based chemistry experiments. Hong Kong: Government Logistics Department.

[11] Cheung, H.Y. (2008). Teacher efficacy: A comparative study of Hong Kong and Shanghai primary in-service teachers. The Australian Educational Researcher, 35 (1), 103-123.

[12] Hofstein, A., \& Lunetta, N. V. (1982). The role of the laboratory in science teaching: Neglected aspect of research. Review of Educational Research, 52 (2), 201-217.

[13] Domin, D.S. (1999). A review of laboratory instruction styles. Journal of Chemical Education, 76(4), 543-547.

[14] Hofstein, A., \& Lunetta V.N. (2003). The laboratory in science education: Foundations for the twenty-first century. Science Education, 88 (1), 28-54.

[15] Gülçiçek, Ç.(2009) Comparison of the effects of verification laboratory approach with simulation aided verification laboratory approach in eliminating the misconceptions concerned some mechanics concepts (Unpublished doctoral dissertation). Gazi University, Ankara, Turkey.

[16] [16] Singer, S. R., Hilton, M. L., \& Schweingruber, H. A. (2006). America's lab report: Investigations in high school science. Washington, DC: National Academies Press.

[17] Bajzek, D., Burnette, J., \& Brown, W. (2005). Building cognitively informed simulators utilizing multiple, linked representations which explain core concepts in modern biology. In Proceedings of World Conference on Educational Multimedia, Hypermedia and Telecommunications 2005 (pp. 3773-3778). Norfolk, VA: AACE. 
[18] Bozkurt, E., \& Sarıkoç, A. (2008). Can the virtual laboratory replace the traditional laboratory in physics education? Selçuk Unıversity Journal of Ahmet Keleşoğlu Education Faculty, 25, 89-100.

[19] Callıca, H., Erol, M., Sezgin, G., \& Kavcar, N. (2001). A study on laboratory applications in primary schools. In Proceedings of at 4th Conference of Science Education, 217-219. Ankara: National Education Press.

[20] Feyzioğlu, B., Akçay, H., \& Pekmez, E.Ş. (2007). Comparison of the effects of computer assisted cooperative and individualistic learning in chemistry on students' achievements and attitudes. Strasbourg: AREF.

[21] Kaptan, F. (1999). Fen bilgisi öğretimi. İstanbul: MEB Yayınları Öğretmen Kitapları Dizisi.

[22] Özdemir, M., \& Kaptan, F. (2013). An investigation of pre-service primary teachers' science process skills and attitude toward science education. Karaelmas Journal of Educational Sciences, 1, 62-75.

[23] Koballa, T. R. \& Crawley, F. E. (1985). The influence of attitude on science teaching and learning. School Science and Mathematics, 85, 222-232.

[24] Mattern, N., \& Schau, C. (2001). Gender difference in attitude-achievement relationships over time among white middle school students. Journal of Research in Science Teaching. 39, 324-340.

[25] Haney, J., Czerniak, C. \& Lumpe, A. (1996). Teacher beliefs and intentions regarding the implementation of science education reform standards. Journal of Research in Science Teaching, 33, 971-993.

[26] Palmer, D. H. (2002). Factors contributing to attitude exchange amongst pre-service elementary teachers. Science Education, 86(1), 122-138.

[27] Creswell, J. W., \& Plano-Clark, V. L., Designing and conducting mixed methods research. CA: Sage Publications, Thousand Oaks, 2007.

[28] Fraenkel, J. R., \& Wallen, N. E. (2000). How to design and evaluate research in education (4th ed.). Boston: McGraw-Hill.

[29] Özkan,Ö., Tekkaya, C., \& Çakıroğlu, J. (2002). Fen bilgisi aday öğretmenlerin fen kavramlarını anlama düzeyleri, fen ögretimine yönelik tutum ve öz yeterlik inançları. V. Ulusal Fen Bilimleri ve Matematik Egitimi Kongresi. Ankara.

[30] Thompson, C. L., \& Shrigley, R. L. (1986). What Research Says. School Science and Mathematics, 86(4), 331-343.

[31] Yıldırım, A., \& Şimşek, H. (2011).Sosyal Bilimlerde Nitel Araştırma Yöntemleri.Ankara: Seçkin Yayıncılık.
[32] Miles, M. B., \& Huberman, A.M. (1994). Qualitative Data Analysis: An Expanded Sourcebook. (2 ${ }^{\text {nd }}$ Edition). Calif.: SAGE Publications.

[33] White,S.R., \& Bodner, M.G. (1999). Evaluation of computer simulation experiments in a senior level capstone chemical engineering course. Chemical Engineering Education, 33(1), 34-39.

[34] Rutten, N.,Joolingen, W. R., \&Van der Veen, J. T. (2012). The learning effects of computer simulations in science education. Computers \& Education, 58, 136-153.

[35] Sarı, U., Ulukök, Ş., \& Özdemir, F.Z. (2013). The effect of virtual laboratory applications for "Electricity in our life" unit on science process skills and attitudes. Mediterranean Journal of Educational Research, 14a, 650-655.

[36] Çepni, S. Taş, E., \& Köse, S. (2006). The effects of computer-assisted material on students' cognitive levels, misconceptions and attitudes towards science. Computers \& Education, 46(2), 192-205.

[37] Güven, G., \& Sülün, Y. (2012). The effect of computer assisted instruction on $8^{\text {th }}$ grade students achievement levels in science course and on their attitudes towards the course. Journal of Turkish Science Education, 9(1), 68-79.

[38] Adams, W. K.,Perkins, K. K., Podolefsky, N. S., Dubson, M., Finkelstein, N. D., \& Wieman, C. E. (2006). A new instrument for measuring student beliefs about physics and learning physics: the colorado learning attitudes about science survey. Physical Review Special Topics - Physics Education Research, 2(1), 1-14. doi: 10.1103/PhysRevSTPER.2.010101

[39] Bozkurt, E. (2007). Effect of a virtual laboratory applications prepared in physics education compared to traditional laboratory on student success: the RC circuit sample in direct current. Retrieved fromhttp//pietc2008.home.anadolu.edu.tri etc200860.doc

[40] Özdener, N. (2005). Using simulations in experimental teaching methods. The Turkish Online Journal of Educational Technology, 4(4), 93-98. Retrieved from http://www.tojet.ne t/articles/4413.pdf

[41] Wieman, C. E., \& Perkins, K. K. (2006). A powerful tool for teaching science. Nature Physics, 2, 290-292.

[42] Sarı,U., \& Güven, G.(2013). Etkileşimli tahta destekli sorgulamaya dayalı fizik öğretiminin başarı ve motivasyona etkisi ve öğretmen adaylarının öğretime yönelik görüşleri. Necatibey Faculty of Education Electronic Journal of Science and Mathematics Education, 7(2), 110-143.

[43] Ulukök, Ş., Çelik, H., \& Sarı, U. (2013). The effects of computer-assisted instruction of simple circuits on experimental process skills. Journal of Theoretical Educational Science 6(1), 77-101. 